\title{
The Relationship Between Work Engagement and Burnout in Ditpolair Korpolairud Baharkam Polri
}

\author{
Rizky Mukti Aryatno \\ ${ }^{1}$ Department of Psychology, Universitas Negeri Yogyakarta, \\ Jl. Colombo No. 1 Karang Malang Sleman, Yogyakarta \\ ${ }^{1}$ rizkymukti17@gmail.com
}

\begin{abstract}
The aim of this study was to investigate the relationship between work engagement and burnout in Korpolairud Ditpolair Baharkam Polri. This study was a correlational study with quantitative method. 120 members of Korpolairud who worked in the Subditpatrolair division were involved as participants. Simple random sampling was used as sampling method and 4 point Likert scale as data collection techniques. The work engagement scale was based on Schaufeli's theory with aspects namely vigor, dedication, and absorption. Menawhile, the burnout scale was based on Maslach's theory with aspects namely emotional exhaustion, depersonalization, and personal accomplishment. Based on data analysis using Pearson Product-Moment correlation test, the results of this study showed that there was a correlation between work engagement and burnout in Korpolairud Ditpolair Baharkam Polri as proved by -0.752 coefficient value and $p=0.00$. It can be concluded that the correlation between work engagement and burnout was significant and negatively correlated.
\end{abstract}

Keywords: Burnout, work engageme

\section{Introduction}

Indonesia is a country with a large area of water. This makes activities such as illegal fishing, smuggling, and even conflict in border areas often occur. One of the institutions tasked with protecting Indonesia's territorial waters is the Kopolairud Ditpolair Baharkam Polri. Korpolairud has the duty to serve, protect, protect, and maintain the security and order of the community and law enforcement in the territorial waters of Indonesia.

The assignment period given to Ditpolair Members is usually around 1 year. The members are also required to always be prepared with various incidental tasks given by the leadership. These various tasks sometimes tend to make them tired and even stressed. Police members who are unable to coping stress well will tend to experience burnout (Rizkinannisa, 2017: 15).
Based on preliminary interviews conducted by researchers to 3 members of Ditpolair said that they experienced burnout. They said that he experienced fatigue during work, sometimes even experiencing physical pain when working. They explained that this happened because of task uncertainty and the number of incidental tasks that made them too busy and eventually exhausted. They also said that they had behaved cynically, such as swearing or snapping at other colleagues while working. This is usually caused by differences of opinion between them and the seniors. Based on interviews it was also known that they felt their performance was declining and felt their achievements or catch were not as good as in the previous year. Burnout is a syndrome of emotional exhaustion and cynicism that occurs in someone when working (Maslach \& Jackson, 1981: 91). According to him 


\section{The Relationship Between Work Engagement and Burnout Rizky Mukti Aryatno}

someone who burnout experience emotional exhaustion and tend to behave negatively when working. They also tend to decrease performance at work.

According to Maslach \& Jackson (1981: 101) there are 3 aspects of burnout, namely emotional exhaustion, depersonalization, and decreased personal achievement. Emotional fatigue is described as feeling of saturation and excessive fatigue at work. Depersonalization is an attempt by someone to make a distance between themselves and clients by ignoring the qualities that they should be able to give or being cynical with those around them. Meanwhile, a decrease in personal achievement is a tendency to evaluate themselves negatively, especially those related to work.

There are 2 factors that can influence burnout, namely situational factors and individual factors (Maslach, Schaufeli, \& Baker, 2001). In situational factors, there are job characteristics, job characteristics, and organizational characteristics. Meanwhile, individual factors are influenced by demographics, personality, and work attitudes. One other factor that also affects burnout is work engagement (Hussein, 2018: 921).

According to Baker \& Leiter (2010: 1) work engagement is a state of mind that is positive, satisfying, and bound between a person and his work. According to him work engagement is also synonymous with a high level of enthusiasm in a person. Someone engaged with their work has positive thoughts and is satisfied with the work they do, and feels bound to the work.

According to Schaufeli et al (in Bakker \& Leiter, 2013: 13) aspects of work engagement are vigor, dedication, and absorption. Vigor describes the high level of energy and mental endurance of a person at work. Dedication refers to the strong involvement of a person with his work, enthusiasm, inspiration, pride, and challenges in a job. Absorption is characterized by full concentration and feeling happy about work, where time passes quickly so that it has difficulty in breaking away from work.

Research conducted by Rahayu (2019) shows that the level of work engagement among police officers tends to be high. According to him this is caused by the characteristics of the work which is quite challenging. Initial interviews conducted by researchers with 3 members of Ditpolair also showed that the three members felt engaged with their work. This difficult level of selection makes them proud to be accepted as members of the National Police. They also felt that the facilities provided by management were very satisfying.

Although work engagement among police officers tends to be high, it is different from the situation of work engagement in other professions. Aon Hewitt's survey of 6.7 million employees in more than 2,900 companies in the world shows a decrease in the level of employee engagement from $60 \%$ in 2009 to $56 \%$ in 2010.

According to Maslach \& Leiter (1997) burnout can also occur when aspects of work engagement, vigor, absorption, and dedication owned by employees turn into exhaustion, cynicism, and inefficacy. Employees who initially have high enthusiasm and desire to work turn into looking tired and hating their work when experiencing burnout. This indicates that there is a relationship between work engagement with burnout.

Research conducted by Upadaya, Vartiainen, and Salmela-Aro in 2012 proved that there is a relationship between work engagement and burnout. However, the research conducted by Hikmatullah (2016) on work engagement with burnout to 70 employees working in the IT field shows that these two variables have no relationship when researched by him. This shows the pros and cons related to the 


\section{The Relationship Between Work Engagement and Burnout Rizky Mukti Aryatno}

relationship of work engagement with burnout.

Based on the problems that have been previously explained, the police have a high level of work engagement, but the police also have a great tendency to burnout. Researchers want to see whether there is a relationship between work engagement with burnout on the Ditpolair Korpolairud Baharkam Polri. The researcher hopes that this research can illustrate the relationship between these two variables and can provide information to relevant institutions regarding the level of work engagement and burnout to their members.

\section{Methods}

Types of research

In this study using a quantitative approach. This type of research based on the function and characteristics of the problem is categorized as correlational research. Correlational research is research that aims to determine the strength and direction of the relationship between variables that are used as the focus of research (Azwar, 2018: 7).

Time and Place of Research

This research was conducted at Ditpolair Korpolairud Baharkam Polri which is located on Jalan Re Martadinata 1 No. 1, Tanjung Priok, North Jakarta, Jakarta. The research began on April 25 2019 until July 25, 2019.

\section{Participants}

The population in this study were 600 members of the Polytechnic Police Department Baharkam Ditpolair who served in the Subditpatrolair section. Based on the Yamane formula the samples that must be used in this study are 220 people. However, due to various limitations encountered by researchers while retrieving data, the subjects that succeeded the researchers were as many as 120 people.
The sampling technique used by researchers is simple random sampling.

\section{Research Procedure and Intruments}

This research consists of several stages. First, researchers take care of licensing with related management. Next the researchers collected data by distributing burnout scales and work engagement to the 120 members of Subditpatrolair. The instrument was disseminated online with the whats app and through offline by directly meeting Subditpatrolair members who were at headquarters. After the data is collected, the researcher chooses the items by removing the items that have a total correlation value below 0.25. According to Azwar (2015: 139) the minimum limit on the total item correlation coefficient is 0.30 , but the limit can be reduced to 0.25 .

Data collection techniques used in this study is to use a Likert Type scale. The term Likert Type is used because in this study the Likert scale was modified from 5 answer choices to 4 answer choices. Answer choices consist of Very Appropriate (SS), Appropriate (S), Unsuitable (TS), and Very Unsuitable (STS). Scale is spread through offline and online.

There are 2 instruments used in this study, namely Burnout Scale and Work Engagement Scale. The Burnout scale was made based on Maslach's theory which uses 3 aspects to describe burnout, namely emotional exhaustion, depersonalization, and decreased personal achievement. Meanwhile, the Work Engagement Scale was formed based on the theory from Bakker with 3 aspects of work engagement, namely vigor, dedication, and absorption. The Burnout Scale and the Work Engagement Scale each contain 26 items.

\section{Data Analysis}

Data analysis techniques used in this study were descriptive analysis, test requirements, and hypothesis testing. Descriptive analysis is used to categorize 


\section{The Relationship Between Work Engagement and Burnout Rizky Mukti Aryatno}

the research variables. Test requirements include normality test and linearity test. While testing the hypothesis using Pearson Product Moment correlation analysis. The validity used in this research is to use expert judgment. Meanwhile, the reliability of the Burnout Scale is 0.90 and the reliability of the Work Engagement Scale is 0.88 .

\section{Findings and Discussion}

\section{Location Overview}

Korpolairud is an abbreviation of the Marine and Air Police Corps. Meanwhile, Ditpolair is the main implementing element under Korpolairud. In his duty Ditpolair is assisted by Subditpatrolair. Subditpatrolair is tasked with organizing Area patrols and escorting Police Ships in order to provide protection and services so that order can be created in the community.

Members in the Subditpatrolair section tend to be on duty for long voyages. At the time of the study, most members of Subditpatrolair were carrying out tasks surrounding the territorial waters of Indonesia. Meanwhile, the condition of office facilities and ships that are leaning is very adequate. Even in various corners of the headquarters already provided wifi to access the internet.

\section{Overview of Research Subjects}

The majority of research subjects are under 30 years old and have worked for 6 to 10 years. Most of the subjects in this study also have a senior high school / equivalent level and are married. Based on the analysis it is also known that the subject consists of the rank of Bripda to Aitpu.

\section{Variable Description}

Based on descriptive analysis of the research data obtained description of the burnout variable data which can be seen in Figure 1.
Figure 1. Graph of Burnout Variables

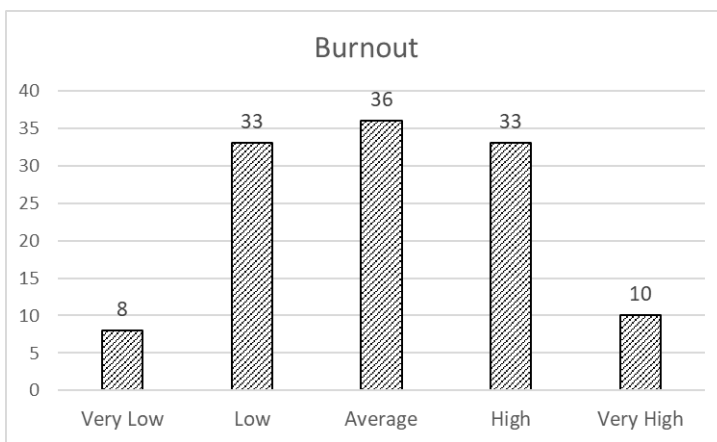

In Figure 1. it can be seen that the level of burnout on the subject tends to be moderate. Next, a description of the work engagement variable data can be seen in Figure 2.

Figure 2. Graph of Work Engagement Variables

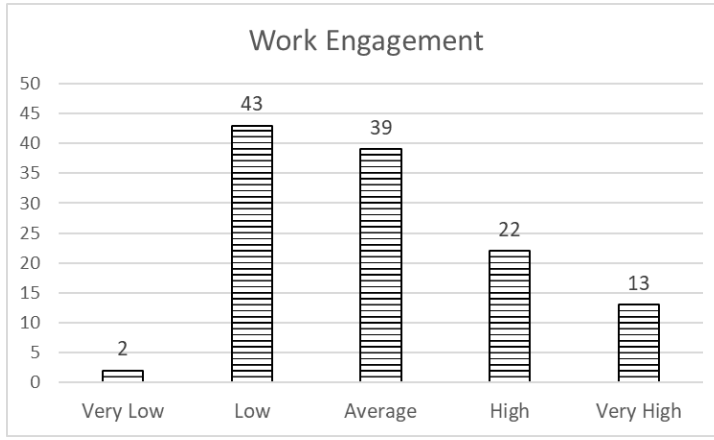

Based on Figure 2. it can be seen that the majority of subjects have a low level of work engagement.

\section{Research Test Results}

The following are the results of a research test consisting of the results of the test requirements and the results of hypothesis testing:

1) Test Requirements

The requirements test results consist of the results of the normality test and the linearity test which are known as follows: 
Table 1. Residual Transform Data

Normality Test Results.

\begin{tabular}{cc}
\hline $\begin{array}{c}\text { Signifikansi } \\
\text { Kolmogorov- Smirnov }\end{array}$ & Explanation \\
\hline 0.20 & $\begin{array}{c}\text { Normally } \\
\text { Distributed }\end{array}$ \\
\hline
\end{tabular}

Based on Table 1. Shows the value of $0.20>$ 0.05. This indicates that the data in this study are normally distributed.

Table 2. Linearity Test Results

\begin{tabular}{ccc}
\hline Linearity & $\begin{array}{c}\text { Deviation } \\
\text { From Linearity }\end{array}$ & Explanation \\
\hline 0.00 & 0.475 & Linear
\end{tabular}

Based on Table 2. shows the results of the linearity test has a significance value of 0.475 and a linearity value of 0.00 . In this study $0.475>0.05$ which indicates that there is a linear relationship between work engagement and burnout.

\section{2) Hypothesis Test}

Hypothesis testing in this study uses the Pearson Product Moment correlation test. This analysis is used if the two variables are linearly related and normally distributed (Yamin, Rachmach, \& Kurniawan, 2011: 218).

Table 3. Hypothesis Test Results

\begin{tabular}{cc}
\hline $\begin{array}{c}\text { Pearson Product } \\
\text { Moment Correlation }\end{array}$ & Sig \\
\hline-0.752 & 0.00
\end{tabular}

Based on Table 3. it can be seen that the value of $r=-0.752$ and $p=0.00$. In these data it can be seen that $0.00<0.05$ which means that the two variables have a significant relationship.
Discussion

Based on the results of descriptive analysis shows that $30 \%$ or the majority of research subjects experienced moderate burnout. Meanwhile, the level of work engagement on the subject tends to be low.

The results of hypothesis testing using Pearson Product Moment show that the correlation value of the two variables of this study is -0.752 with a significance of 0.00 . This indicates that there is a strong and significant negative relationship between work engagement and burnout at Ditpolair Korpolairud Baharkam Polri.

Maslach \& Leiter (1997) said that burnout is an erosion of the level of work engagement in a person. The difficult level of selection makes new members accepted by these agencies be proud and tend to be engaged with their profession when they first work. However, over time and experiencing various problems while on duty, the level of burnout in themselves has increased and the level of work engagement in him has decreased.

According to Ceyhun \& Ozbag (2014) members of the navy have working conditions that trigger burnout. Ditpolair members who work on board feel that the length of time they are on duty is too long. They are also required to carry out incidental tasks related to securing the conflicts that often occur in Indonesia. Zakir \& Murat (in Rizkinannisa, 2017) said that the profession as a police officer is a job with a high level of stress due to long working hours, leadership structure, and high concerns for the safety of oneself and others.

According to Maslach, Schaufeli, \& Leiter (2001: 409: 411) burnout tends to be more often experienced by workers who are married, have a high level of education, are under 30 years old, and tend to be higher in women. The average subject of this study is married and the average age is under 30 years. This can be one factor that causes burnout on members. Meanwhile, one 
factor that can reduce the level of burnout is work engagement (Hussein, 2018).

The level of work engagement on the subject of this study tends to be low. Based on Halbesleben's opinion (in Bakker \& Leiter, 2010: 110), the factors that influence the level of work engagement are burnout, demand, resources, and outcomes. The members said that they felt they had a heavy workload, the tasks assigned to them were not appropriate and tended to be incidental. The task given to sail also felt too long by the members. The members also said that their performance results were no better than the previous year.

Although the level of work engagement of subjects is low, the level of burnout in them tends to be moderate. According to Updaya, Vartianien, \& Slamela-Aro (2016) the lower the work engagement, the higher the level of burnout. This is different from the results of descriptive analysis of research data which shows a low level of work engagement, but the level of burnout tends to be moderate.

According to Natalia (2016: 99) organizational culture is negatively related to burnout. According to him, people who have and can inspire the culture of their organization, the level of burnout in themselves will decrease. The members of Ditpolair have been educated to have the spirit of a knight, so that no matter how difficult their tasks. They must remain enthusiastic in carrying out the tasks given. This makes the level of burnout on the subject tends to be moderate.

\section{Limitations of Research}

The following are the limitations in this study:

1. At the time of the research the members tended to be on duty, so there were only a few members who were at the headquarters.
2. The absence of signals in the ocean makes members who are on duty unable to become subjects in this study.

3. The time for researchers to retrieve data is very limited.

4. The number of subjects in this study cannot meet the minimum number of subjects with an error rate of $5 \%$.

\section{Conclusion}

Based on the analysis using Pearson Product Moment, the correlation coefficient value is -0.752 and significance 1.1. This indicates that there is a negative and significant relationship between work engagement with burnout at Ditpolair Korpolairud Baharkam Polri.

\section{Suggestion}

1. For the Institution, the management is expected to be able to know what problems occur to its members. This can be done using Focus Group Disscus (FGD) with members or by providing a criticism box.

2. For members, members are expected to be able to maintain enthusiasm and be able to overcome boredom while on the ship. This can be done by doing various activities together such as playing video games or sports together while sailing on the ship.

3. For the community, the community is expected to also explore various other literacies related to this research to enrich their literacy.

4. For other researchers, other researchers are expected to be able to conduct research related to the development of these two variables in the future, and pay attention to the factors that influence them such as workload, age, and marital status. 


\section{References}

Azwar, S. (2015). Validitas dan Reliabilitas (Edisi 4). Yogyakarta: Pustaka Pelajar.

Bakker, A.B., Leiter M.P. 2010. Work Engagement: A Hanbook of Essential Theory and Research. East Susex: Psychology Press.

Bakker, A. B., Schaufeli, W. B., Leiter, M. P., \& Taris, T.W. 2008. Work engagement : An emerging concept in occupational health psychology. Work \& Stress, 22, 187-200.

Ceyhun, G. C., \& Ozbag, G. K. 2014. Does Burnout Working Condition Affect Marine Pilot Job

Satisfaction and Turnover Intentions. International Journal of Academic Research in Business and Social Sciences. Vol. 4, No. 3, 2222-6990.

Hikmatullah, F. 2016. Hubungan Employee Engagement Dan Burnout Pada Karyawan Divisi IT. Jurnal Ilmiah Psikologi, Vol 9. No. 1, 100-108.

Hussein, S. 2018. Work Engagement, Bunrout and Personal Accomplishments Among Social Workers: A Comparison Between Those Working in Children and Adults' Services in England. Administrartion and Policy in Mental Health and Mental Health Services Research, 45, 911-923.

Rizkinannisa. 2017. Pengaruh Coping Stress Terhadap Burnout Anggota 